\title{
Charles Darwin and Human Evolution
}

\author{
Ian Tattersall
}

Published online: 6 December 2008

(C) Springer Science + Business Media, LLC 2008

Along with his younger colleague Alfred Russel Wallace, Charles Darwin provided the initial theoretical underpinnings of human evolutionary science as it is practiced today. Clearly, nobody seeking to understand human origins, any more than any other student of the history of life, can ignore our debt to these two men. As a result, in this bicentennial year when Darwin's influence in every field of biology is being celebrated, it seems reasonable to look back at his relationship to paleoanthropology, a field that was beginning to take form out of a more generalized antiquarian interest just as Darwin was publishing On the Origin of Species in 1859. Yet there is a problem. Charles Darwin was curiously unforthcoming on the subject of human evolution as viewed through the fossil record, to the point of being virtually silent. He was, of course, most famously reticent on the matter in On The Origin of Species, noting himself in 1871 that his only mention of human origins had been one single throwaway comment, in his concluding section:

"light will be thrown on the origin of man and his history" (Darwin 1859, p. 488).

This has, of course, to rank among the most epic understatements ever. And of course, it begged the question, "what light?" But in the event, Darwin proved highly resistant to following up on this question. This is true even of his 1871 book The Descent of Man, and

\section{Tattersall $(\bowtie)$}

Division of Anthropology,

The American Museum of Natural History,

New York, NY 10024, USA

e-mail: iant@amnh.org
Selection in Relation to Sex in which Darwin finally forced himself to confront the implications of his theory for the origin of humankind, and the main title of which is in many ways something of a teaser.

There were undoubtedly multiple reasons for this neglect of the issue that was naturally enough in the back of everyone's mind when reading The Origin, let alone The Descent of Man. First, and most famously, there was the intellectual and social milieu in which Darwin lived. During the second quarter of the nineteenth century, during which Darwin's most formative experiences all occurred, England was at one level a place of intense political and social ferment. The Reform Act of 1832 had witnessed significant changes in the way Parliament was elected; the New Poor Law of 1834 had at least recognized problems in the system of poverty relief; and the founding of London University in 1826 had provided, at last, a secular alternative to the fusty Anglican Universities of Cambridge and Oxford. But despite all this, early Victorian England remained a straitlaced Anglican society whose upper classes, well remembering events in France not so long before, had little taste for radical ideas in any field.

In such an unreceptive milieu, the retiring Darwin had little relish for stirring things up with radical ideas on human emergence. He had originally planned to include mankind in the "Big Book" he was working on when spurred by Wallace into writing and publishing its "abstract" in the form of On the Origin of Species (Moore and Desmond, 2004). But despite having then made the conscious decision to avoid the vexatious and contentious issue of human evolution in On the Origin of Species, he still saw his book widely condemned as intellectual heresy, even as a recipe for the ruin of established society. As a 
result, while contemplating the publication of The Descent of Man a decade later, Darwin was still able to write to a colleague that:

"When I publish my book, I can see that I shall meet with universal disapprobation, if not execution" (in a letter to St. George Mivart, April 23, [probably] 1869).

As the least combative of men, Darwin dreaded the response he knew that any attempt to stake out a position on human origins would receive. And to be quite frank, given all his hesitations, it is not at all clear to me exactly why Darwin felt so strongly impelled to publish The Descent of Man or at least to have given it the provocative if not quite accurately descriptive title he did.

One possibility is merely that, during the 1860 s, such luminaries as Alfred Russel Wallace, Ernst Haeckel, and Thomas Henry Huxley had all publicly tackled the matter of human origins and not invariably to Darwin's satisfaction. As a result, Darwin may simply have felt it necessary to make his own statement on the matter, come hell or high water, in a decade that was already significantly more receptive to evolutionary notions than the 1850 s had been. As to why it was so important to him to see it written, the Darwin historians James Moore and Adrian Desmond have pointed to an agenda that did not translate directly from Darwin's stated desire simply:

"to see how far the general conclusions arrived at in my former works were applicable to man... all the more desirable as I had never applied these views to a species taken singly" (Darwin 1871, ii, p. 2).

There was clearly more to it than that, and Moore and Desmond emphasize that Darwin came from a family of free-thinkers. He was the grandson both of the libertarian poet and physician Erasmus Darwin and of the Unitarian Josiah Wedgwood who had, in 1787, produced the famous "am I not a man and a brother?" cameo that became the emblem of the movement to abolish slavery. What is more, at a very impressionable age, Charles had attended the more or less secularist Edinburgh University in Scotland. There he had studied under the anatomist Robert Grant who quoted Lamarck with approval; and there also he was taught taxidermy by John Edmondston, a freed slave from British Guiana for whom he developed very considerable respect.

From the very beginning, then, Darwin abhorred slavery; and he was already a convinced abolitionist by the time he boarded the Beagle in 1831 for his formative round-theworld voyage. His subsequent experiences in Brazil, where he witnessed hideous cruelties being inflicted on slaves, and in Argentina, where he saw the pampas Indians being slaughtered to make way for Spanish ranchers, only confirmed him in his egalitarian beliefs. This concern linked in with Darwin's strong views on the unity of mankind. In the early and middle nineteenth century, this was a very hot topic in the English-speaking world, even "the question of the day," as the blurb to a book by the Presbyterian abolitionist Thomas Smyth (1850) put it.

The precise question at issue was of course whether the races of mankind had been separately created (or even, after The Origin of Species was published, descended from different species of apes), as the proslavery polygenists proposed; or whether they were simply varieties of one single species, as proclaimed by the antislavery monogenists.

In this matter, there was little hope that science could ever be disentangled from politics; and it was this, above anything else, it seems, that had dissuaded Darwin from including humans in On the Origin of Species. By 1871, however, the world had changed enough to allow Darwin to contemplate entering the fray; and there is substantial reason for viewing The Descent of Man as Darwin's contribution on the monogenist side to the monogenism versus polygenism debate - although Moore and Desmond (2004) make a strong argument that, in the end, it became at least as important to Darwin as a showcase for his notion of sexual selection.

Indeed, these two aspects could hardly be separated, since sexual selection - in other words, mate choice-was Darwin's chosen mechanism to explain:

"the divergence of each race from the other races, and all from a common stock" (Darwin 1871, ii, p. 371).

And most of the book is, in true Darwinian style, taken up with hugely detailed documentation of sexual selection among organisms, in support of the proposition that humankind was simply yet another product of Nature, albeit with many of its peculiar features governed by mate choice rather than by adaptiveness.

Still, Darwin had chosen to title his book The Descent of Man. And "descent" was a word that he had long used as equivalent to "ancestry."

Given which, it seems at the least a bit odd that in the entire two volumes of the first edition of the work only passing consideration at best is given to those fossils that might have given a historical embodiment to the notion of human emergence. Even when Darwin wrote the Origin in 1858-1859, a handful of "antediluvian" human fossils was already known. The most famous of these was the skullcap and associated bones discovered in 1856 in the "Little Feldhofer Grotto," a limestone cave in the Neander Valley, near Dusseldorf in Germany. This fossil, associated with the bones of mammal species now extinct, was destined in 1863 to become the type specimen of Homo neanderthalensis, now known to be an extinct cousin of our own species, 
Homo sapiens. But it was not published until 1858, barely a year before the Origin appeared; and even then, it was described in German, in a rather obscure local scientific journal, making it highly unlikely that the Neanderthal fossil came to Darwin's attention before Hermann Schaaffhausen's work on it was translated into English by the London anatomist George Busk in 1861. Still, this was an entire decade before The Descent of Man first appeared, which makes it a little odd that the detail-obsessed Darwin made virtually no reference to the Feldhofer fossil in a book which one might have expected to find it at front and center or at least introduced as a phenomenon to be explained. Only in passing did he mention it at all.

The neglect of the Neanderthal fossil is all the more remarkable in light of the fact that, in 1863, George Busk had already described another individual, of similarly distinctive appearance, from the British possession of Gibraltar. Taken together, these two specimens had demonstrated pretty conclusively by the mid-1860s that here was not simply a pathological form of Homo sapiens, as many influential biologists had claimed, but at the very least a highly distinctive human "variety" that needed explanation of some kind. In sharp contrast to any modern human fossils then known from anywhere in the world, the Neanderthal skull was very long and low. What's more, it terminated in front in prominent brow ridges that arced individually above each eye and at the rear in a curious bulge that became known as a "chignon" or "bun." On the other side of the balance, this skull had evidently contained a brain that was equal in size to the brain that resided in the heads of modern people. Either way, it was obviously an important fossil.

Yet the only reference that the astonishingly erudite Darwin made to this fossil, in almost 800 pages of dense text, was in the context of a throwaway admission that:

"some skulls of very high antiquity, such as the famous one of Neanderthal, are well developed and capacious." (Darwin 1871, i, p. 140).

It is hard not to conclude that, in limiting his reference to the Feldhofer in this way, Darwin was grasping at the politically congenial notion that the Neanderthaler, ancient as it was, was simply a bizarre kind of modern human. For perhaps more remarkably yet, nowhere in The Descent of Man did Darwin directly confront the idea that the human species might even in principle have possessed extinct relatives - despite the fact that the entire Origin of Species is suffused with the notion that having extinct relatives must be a general property of all living forms.

In his introduction to The Descent, Darwin partially excused himself for only passing reference to human antiquity by deferring to the work of Jacques Boucher de Perthes, Charles Lyell, his protégé Sir John Lubbock, and others. But there was very likely another key to Darwin's reluctance to embroil himself too closely with the actual tangible evidence for human ancientness and ancestry. For the $1860 \mathrm{~s}$, the years leading up to the publication of the Decent of Man, were a period of rampant fraud and fakery in the antiquities business - and a business it certainly was. By the time Darwin published the Descent, it was widely accepted that, at the very least, the human past far antedated Biblical accounts. And an energetic search was on for evidence of that ancient past, with wealthy dilettantes pouring money into excavations all across Europe. Today, we honor the French antiquarian and customs-collector, Boucher de Perthes, as the first man to recognize the Ice Age stone handaxes found in the terraces of the Somme River as the products of truly ancient humans. But in the 1840 s and 1850 s, Boucher de Perthes was widely ridiculed as the gullible victim of hoaxers; and indeed, it is true that he was entirely undiscriminating in what he was prepared to consider ancient. Many of his prize artifacts turned out later to have been knapped by his quarrymen, who were only too happy to con their employer out of a few francs. Indeed, there is a charming story of a lady who asked a local peasant what he was doing chipping away at a piece of flint and was told: "Why, I am making Celtic handaxes for Monsieur Boucher de Perthes." "Celtic" was then the current term for anything prehistoric.

Of course, Boucher de Perthes was not alone. For profitable deception of the gentry, by clever tricksters from the underclasses, was a rather sporting component of class warfare all across Europe in the mid - nineteenth century. But Boucher de Perthes had, in particular, been embroiled in a famous hoax involving a supposedly antediluvian human fossil (Trinkaus and Shipman 1993). In early 1863, he offered a reward of 200 francs to any workman who could find the remains of the maker of his ancient stone tools. And on March 28 of that year, a supposedly ancient human jawbone duly showed up, along with handaxes, at a site called Moulin-Quignon. A scandal almost immediately blew up over the authenticity of this object and the stone tools supposedly associated with it; and eventually, an international commission was convened to settle the matter. This committee of savants consisted of various French luminaries, plus several English scientists including George Busk. Eventually, the commission exonerated Boucher de Perthes himself as a fraudster, but remained deadlocked over the authenticity of the fossil and tools. The French intelligentsia mostly accepted them for political reasons, while the English remained opposed. And the whole affair added up to the sort of unseemly squabble that Darwin most detested and always did his best to avoid.

What's more, there were similar and equally embarrassing scandals closer to home. In England, the so-called 
"Prince of Counterfeiters" was one Edward Simpson, alias "Flint Jack" (Milner 2008). During several years of assisting a local physician who dug for antiquities in his spare time, Flint Jack taught himself the art of stoneworking. Soon, this gifted flintknapper was producing supposedly Stone Age tools that would fool even the most expert eye. And he sold his forgeries to collectors and museums all over the country. Finally, he brazenly peddled them as his own work, before the sheer quantity of real Stone Age artifacts coming on to the market put him out of business. There can be little doubt that Darwin found all this fraud and scandal in the antiquarian marketplace very distasteful. And it must surely have been at least one more contributory factor in his reluctance to dabble in the human fossil record.

Still, it is nonetheless necessary to ask why Darwin gave even the idea of an actual fossil ancestry for humans such a wide berth in his great work on human descent. In this connection, it is quite possibly enough to conclude with Moore and Desmond (2004) that Darwin considered it simply too provocative, both politically and socially, to tie human ancestry in with any tangible evidence. For it is well known that even the contemplation of doing so caused this complex and delicate man extreme physical and mental distress; and it certainly seems plausible that Darwin felt that limiting himself to the comparative method, contrasting humans with apes, and merely conjecturing about possible transitional forms, was somehow the safest route to take. After all, those speculative intermediates remained hypothetical, unenshrined in any material object that his opponents might take exception to.

However, it is possible that another contributing factor may well have been Darwin's rather suspicious attitude toward the fossil record itself-which in the nature of things is the only direct archive we have of the origins and evolution of the human family or any other. Of course, by its very nature, the fossil record is and always will be incomplete. And in Darwin's time, 150 years ago, it was vastly more incomplete than it is now, and conspicuously lacked many of the intermediate forms predicted by Darwin's theory. But while under such circumstances it is completely understandable that Darwin would not have wished to embrace the fossil record as a key element bolstering his notion, he seems to have deliberately shied away from it. Thus, under the rubric of "Objections to the Theory," he devoted an entire chapter in the Origin of Species to the "Imperfection of the Geological Record," enumerating reason after reason not only why this record was not adequate, but why it could not be adequate.

"Geology assuredly does not reveal any such finely graduated chain [as evolution requires]; and this, perhaps is the gravest objection which can be urged against my theory. The explanation lies, as I believe, in the extreme imperfection of the geological record."

(Darwin 1859, p. 280).

Even in the remarkably brief chapter of the Origin in which he recruited the fossil record to his cause, Darwin was dubious:

"[numerous causes] must have tended to make the fossil record extremely imperfect, and will to a large extent explain why we do not find interminable varieties, connecting together all the extinct and existing forms of life by the finest graduated steps." (Darwin 1859, p. 342).

Darwin's general wariness of the fossil record may seem a bit odd in a person who not only considered himself first and foremost a geologist, but whose nascent ideas about the history of life had been so clearly nourished by the fossils he had encountered during his voyage on the Beagle. For Darwin was always ready to acknowledge what a seminal event his discovery during the Beagle voyage of the amazing South American fossil glyptodonts had been for him. The glyptodonts are large extinct armored xenarthrans, relatives of today's armadillos and sloths, which are found quite abundantly in Ice Age geological deposits of southern South America. And finding these extinct beasts in the very same place as surviving members of their family-something that implied the replacement of faunas by related ones - was a revelation to Darwin:

"[I was] deeply impressed by discovering in the Pampean formation great fossil animals covered with armour like that of the existing armadillos" (C. Darwin in F. Darwin 1950, p. 52).

Indeed, as Eldredge (2005) points out, Darwin's encounter with the glyptodonts constituted one of the three key observations that first led him toward the explicit realization that species were not immutable.

This realization was a truly formative one because, for Darwin, the adoption of the corollary belief in the "transmutation of species" was fundamental to everything that was to follow, and it was emotionally as well as intellectually a difficult transition for him to make. In an 1844 letter to Joseph Hooker, Darwin famously described how admitting his new belief was "like confessing a murder," and it was as formidable a psychological hurdle as he faced in his entire career. Still, although his geological observations had made Darwin acutely aware of the transitory nature of everything he saw around him, he clearly felt very acutely the inadequacies of the fossil record for determining specific events. And although the notion that fossil "missing links" were out there to be 
discovered was soon to become a governing principle of the quest for human origins, Darwin himself seems to have remained rather dubious that such links would ever be found.

Of course, the whole notion of links, missing or otherwise, came from the medieval concept of the Great Chain of Being with which Darwin was philosophically in contention-indeed, in a marginal note in one of the Notebooks, he specifically warned himself against ever using the terms "higher" or "lower" in relation to living beings. But the Great Chain of Being, the idea that all living things were ranged in graded series, was nonetheless part of the ethos that suffused English society, and it was a notion from which Darwin found it difficult to disengage himself entirely. For it was not only a religious concept with a succession of forms leading from the most lowly pond scum, through mankind, the highest Earthly form, on up to the Angels and God above. It had political and social dimensions as well. On one hand, the Great Chain ranked the races of mankind from "lower" to "higher;" and on the other, within English society, it carried through the social order with peasants and servants at the bottom, then tradesmen and the gentry, then the nobility, and on up to royalty at the top who served to link earthly and heavenly existences. Correspondingly, the designations of "lower" and "higher," stemming directly from the Great Chain notion, proved irresistible to zoologists: lemurs, for example, were and still are "lower" primates, while apes and humans are "higher primates."

It is well-established that, long before he published $O n$ the Origin of Species, Darwin was fully aware that his theory firmly placed our species Homo sapiens as simply another product of the evolutionary process, among literally millions of others. So, while the effective absence of a hominid fossil record before he published the Origin may have meant that Darwin could not have made extensive reference to it there if he had wanted to, we still need to ask if there are reasons beyond the admittedly powerful sociopolitical ones why he more or less ignored it in the post-Neanderthal times of The Descent of Man. One reason for such neglect is, of course, the very specific monogenist agenda that Darwin was pursuing in that work. But another reason may be that his colleague Thomas Henry Huxley, who is often, if misleadingly, referred to as "Darwin's Bulldog," had already tackled the matter head-on in his 1863 book of essays, Evidence as to Man's Place in Nature.

The last chapter in Huxley's book was explicitly titled On Some Fossil Remains of Man, and it dealt exclusively with the best-preserved and best-documented fossil humans known at the time: the Neanderthal skullcap already mentioned, and two partial crania from Engis, in Belgium, that had been published by Philippe-Charles Schmerling in the early 1830s. By the time Huxley wrote, the Engis fossils had been certified as contemporaneous with the extinct Ice Age wooly mammoth and wooly rhinoceros by no less an authority than Darwin's close colleague the geologist Charles Lyell, who had also pronounced the Neanderthaler to be of "great but uncertain antiquity." We now know that one of the Engis crania, a juvenile braincase, had belonged to a Neanderthal. However, since many of the osteological differences between Homo neanderthalensis and Homo sapiens only emerge later in development, it is fully understandable that Huxley (like everyone else at the time) did not recognize it as such. And in any event, Huxley basically ignored it. The other Engis cranium was adult, and it was on a plaster cast of this specimen that Huxley based his analysis. The Engis adult clearly is a Homo sapiens and it is now known to represent a later burial into the Neanderthal deposits at the site-which means it is younger than those deposits.

Huxley's ignorance of this fact may not in fact have mattered much, in light of his rather perfunctory and dismissive analysis of the adult Engis specimen. $\mathrm{He}$ recognized this cranium as that of a fully modern person, concluding that it:

"has belonged to a person of limited intellectual faculties, and we conclude thence that it belonged to a man of a low degree of civilization" (Huxley 1863, pp. 114-115).

He then continued to the Neanderthal skull, an altogether more interesting specimen, and to which he devoted much greater space. Initially, he quoted extensively from Schaaffhausen who had declared that the bones:

"exceed all the rest in those peculiarities of conformation which lead to the conclusion of their belonging to a barbarous and savage race." (Schaaffhausen 1861, translated by Busk).

Huxley finally proceeded to a detailed examination of the Neanderthal skullcap, again based on a plaster cast. He was amazed by the differences between the cranial contours of the Neanderthal and Engis crania, but he noted that:

"...the posterior cerebral lobes [of the Neanderthaler] must have projected considerably beyond the cerebellum, and... [this] constitutes one among several points of similarity between [it] and certain Australian skulls" (Huxley 1863, p. 134).

As Schwartz (2006) has pointed out, the comparison with "certain Australian skulls" comes straight out of the Great Chain of Being. For in nineteenth-century European scientific mythology, the Australian aborigines belonged, along with the South African Bushmen, to the "lowest" of 
races. Having established this philosophical baseline, Huxley proceeded to a long dissertation about variation in human skulls, eventually concluding that the key to comparison among them was provided by the basicranial axis, a line between certain points on the internal base of the skull:

"I have arrived at the conviction that no comparison of crania is worth very much, that is not founded upon the establishment of a relatively fixed base line... the basicranial axis." (Huxley 1863, pp. 138-40).

He then showed, to his own satisfaction, that relative to this axis, the basicranium became shorter "in ascending from the lower animals up to man" and that this trend was continued up from the "lower" human races to the "higher" ones. In which case:

"Now comes the important question, can we discern, between the lowest and highest forms of the human cranium, anything answering, in however slight a degree, to this revolution of the side and roof bones of the skull upon the basicranial axis observed upon so great a scale in the mammalian series? Numerous observations lead me to believe that we must answer this question in the affirmative." (Huxley 1863, pp 140-142).

One might object at this point that the basicranial axis had no relevance whatever to the Feldhofer Neanderthal, a specimen that totally lacked a skull base. The important thing here, though, was that Huxley had managed to establish a graded series. And by superimposing the profile of the Neanderthaler onto an Australian skull, he contrived to convince himself that:

"A small additional amount of flattening, and lengthening, with a corresponding increase of the supraciliary ridge, would convert the Australian brain case into a form identical with the aberrant [Neanderthal] fossil." (Huxley 1863, p. 146).

Nonetheless, whereas:

"[The Engis skull] is... a fair average human skull, which might have belonged to a philosopher, or might have contained the thoughtless brains of a savage... The case of the Neanderthal skull is very different. Under whatever aspect... we meet with ape-like characters, stamping it as the most pithecoid of human crania yet discovered" (Huxley 1863, p. 147).

Yet, at the same time, the Neanderthal skullcap had held a large brain-larger, indeed, than the modern average. Furthermore, although the preserved bones of the individual's skeleton were robustly built, Huxley felt that such stoutness was to be "expected in savages" (Huxley 1863, p. 148). As a result, he concluded that:

"In no sense... can the Neanderthal bones be regarded as the remains of a human being intermediate between men and apes. At most, they demonstrate the existence of a man... somewhat toward the pithecoid type... the Neanderthal cranium... forms... the extreme term of a series leading gradually from it to the highest and best developed of human crania" (Huxley 1863, p. 149).

By this intellectual sleight of hand, Huxley dismissed the Neanderthal find as a mere savage Homo sapiens, essentially robbing the slender human fossil record then known of any potential human precursor. Instead, in a move that was as radical in its own way as the alternative would have been, Huxley pushed the antiquity of the species Homo sapiens back into the remotest past and was moved to ask:

"Where, then, must we look for primaeval Man? Was the oldest Homo sapiens pliocene or miocene, or yet more ancient? In still older strata do the fossilized bones of an ape more anthropoid, or a Man more pithecoid, than any yet known await the researches of some unborn palaeontologist?" (Huxley 1863, p. 150).

Taken overall, this rather startling conclusion was not just a major shift away from the demonstrable morphology of the Neanderthal specimen - which in the same year had been branded a distinct species, Homo neanderthalensis, by the Dublin anatomist William King. It was also a considerable reversal of perspective for one who had been a convinced saltationist. After all, when reviewing On the Origin of Species, Huxley had been moved to observe that:

"Mr Darwin's position might, we think, have been even stronger than it is if he had not embarrassed himself with the aphorism 'natura non facit saltum,' which turns up so often in his pages. We believe... that Nature does make jumps now and again, and a recognition of that fact is of no small importance in disposing of many minor objections to the doctrine of transmutation" (Huxley 1860, p. 77).

Famously combative though Huxley was, with none of Darwin's reluctance to hash out in public the implications of evolution for human origins, he too had thus caved when it came to the contemplation of the human fossil record.

What Huxley's motives may have been in this, it is hard to judge. But I am pretty sure that Jeffrey Schwartz (2006) was correct to suggest that, if Huxley had been writing in Man's Place in Nature about any other mammal than a hominid, he would have reached a very different conclusion. Almost certainly, he would have discerned one of Nature's jumps between the Neanderthaler and the avow- 
edly "higher" type from Engis. As it was, however, Huxley elected to reject the idea that the Feldhofer Neanderthal specimen had belonged to "a human being intermediate between men and apes" in favor of viewing it as a member of Homo sapiens, via an extension into the past of the widely assumed "racial hierarchy" that expressed itself in terms not only of morphology, but of technology, society, and presumed intelligence. In a very real sense, then, it is to Huxley that we can trace the exceptionalism that has dogged paleoanthropology ever since.

Historically, however, the significance of Huxley's contribution goes beyond this. For by employing antiDarwinian reasoning in support of the conclusion that the Feldhofer fossil was merely a brutish Homo sapiens, Huxley had provided Darwin with just the excuse he needed not to broach the fossil evidence seriously in The Descent of Man. Darwin could brush the crucial Neanderthal fossil off in passing because Huxley, in however non-Darwinian a spirit and however much in contradiction of his own principles, had given him license to.

There were, then, many reasons why Darwin should have been disposed in The Descent of Man to shrink from any substantive discussion of whether extinct human relatives might actually be represented in fossil form. The fossil and antiquarian records were awash with fakes; any discussion of human ancestry was rife with social and political pitfalls; and anyway, by his own close colleague's testimony, the record contained nothing that could have any relevance to ancient and now-extinct human precursors. Add to that Darwin's innate suspicion of the distorting effects of incompleteness in the fossil record, and he may have felt that a large degree of discretion on the matter was mandatory.

None of this means, of course, that The Descent of Man has not exerted an immense influence on the sciences of human origins over the last century and a half. Just as it is easy for English speakers to forget how much they owe to William Shakespeare for the language they use daily, we tend to lose sight of the fact that much received wisdom in paleoanthropology has come down to us direct from Darwin. Darwin it was who proposed a mechanism for the structural continuity of human beings with the rest of the living world and who gave a detailed argument for human descent from an "ape-like progenitor" (1871, i, p. 59). It was Darwin who documented beyond doubt, in The Descent of Man, that all living humans belong to a unitary species with a single origin - which we now know, on the basis of evidence of which Darwin could never have dreamed, to have been around 200,000 years ago.

$\mathrm{He}$ also had the inspired hunch that our species originated in the continent of Africa - and again, this guess has been amply substantiated by later science. Darwin's perceptions on the behaviors of other primates and how they relate to the way humans behave were remarkably astute, particularly given the highly anecdotal nature of what was then known.

And, for better or for worse, a single comment in The Origin is proclaimed as founding Scripture by practitioners of today's evolutionary psychology industry:

"In the distant future I see open fields for far more important researches. Psychology will be based on a new foundation, that of the necessary acquirement of each mental power and capacity by gradation. Light will be thrown on the origin of man and his history" (Darwin, 1859, p. 488; emphasis added).

Virtually every section in the first part of the Descent of Man foreshadows an area of anthropology or biology that has independently flowered since; and in this way, Darwin wrote much of the agenda that was to be followed by paleoanthropology and primatology over the next century and a half.

I just wish I knew what he really thought about the Neanderthal fossil!

Acknowledgments I would like to thank Niles Eldredge for inviting me to contribute this piece and Richard Milner for the valuable discussion.

\section{References}

Darwin C. On the origin of species. London: John Murray; 1859.

Darwin C. The descent of man and selection in relation to sex. London: John Murrayp. 1871.

Darwin F, editor. Charles Darwin's autobiography. New York: H. Schuman; 1950.

Eldredge N. Darwin: discovering the tree of life. New York: Norton; 2005.

Huxley TH. Evidence as to man's place in nature. New York: Appleton; 1863

Huxley TH. Origin of species, 1860. Republished in Darwiniana: essays. New York: Appleton; 1894. p. 22-79.

Milner R. Darwin's universe. Berkeley, CA: University of California Press; 2008. In press.

Moore J, Desmond A. Introduction. In: Darwin C, The descent of man and selection in relation to sex, 2nd ed. London: Penguin Books; 2004.

Schaaffhausen H. On the crania of the most ancient races of man. Nat Hist Rev 1863;1:155-76. Translated by G. Busk.

Schwartz JH. Race and the odd history of human paleontology. Anat Rec 2006;289B:225-40. New Anat. doi:10.1002/ar.b.20119

Smyth T. The unity of the human races proved to be the doctrine of scripture, reason, and science. With a review of the present position and theory of Professor Agassiz. Charleston SC: Southern Presbyterian; 1850.

Trinkaus E, Shipman P. The Neandertals: changing the image of mankind. New York: Knopf; 1993. 